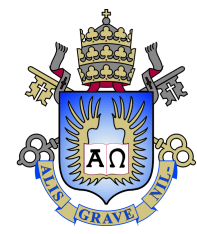

Abel Arrieta Castro

Development of a robust and fault tolerant integrated control system to improve the stability of road vehicles in critical driving scenarios

Tese de Doutorado

Thesis presented to the Programa de Pós-graduação em Engenharia Mecânica of PUC-Rio in partial fulfillment of the requirements for the degree of Doutor em Ciências Engenharia Mecânica.

Advisor : Prof. Hans Ingo Weber

Co-advisor: Prof. Georg Rill 


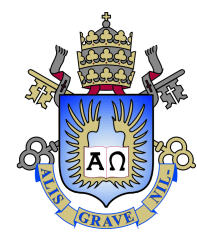

Abel Arrieta Castro

\section{Development of a robust and fault tolerant integrated control system to improve the stability of road vehicles in critical driving scenarios}

Thesis presented to the Programa de Pós-graduação em Engenharia Mecânica of PUC-Rio in partial fulfillment of the requirements for the degree of Doutor em Ciências Engenharia Mecânica. Approved by the undersigned Examination Committee.

Prof. Hans Ingo Weber Advisor

Departamento de Engenharia Mecânica - PUC-Rio

Prof. Georg Rill Co-advisor Fakultät Maschinenbau - OTH Regensburg

Prof. Marco Antonio Meggiolaro

Departamento de Engenharia Mecânica - PUC-Rio

Prof. Ricardo Teixeira da Costa Neto Departamento de Engenharia Mecânica - PUC-Rio

Prof. Mauricio Gruzman Seção de Engenharia Mecânica e de Materiais - IME

Prof. Agenor de Toledo Fleury Escola Politécnica - Universidade de São Paulo

Prof. Márcio da Silveira Carvalho Vice Dean of Graduate Studies Centro Técnico Científico - PUC-Rio 
All rights reserved.

\section{Abel Arrieta Castro}

Graduated in Mechatronic Engineer at the National University of Engineering (UNI) of Peru in 2010 and obtained his M.Sc. Degree in Mechanical Engineer from the Pontifical Catholic University of Rio de Janeiro (PUC-Rio) in 2013.

Bibliographic data

Arrieta Castro, Abel

Development of a robust and fault tolerant integrated control system to improve the stability of road vehicles in critical driving scenarios / Abel Arrieta Castro; advisor: Hans Ingo Weber; co-advisor: Georg Rill. - Rio de Janeiro: PUC-Rio, Departamento de Engenharia Mecânica, 2017.

v., 106 f: il. color. ; $30 \mathrm{~cm}$

Tese (doutorado) - Pontifícia Universidade Católica do Rio de Janeiro, Departamento de Engenharia Mecânica.

Inclui referências bibliográficas.

1. Engenharia Mecânica - Teses. 2. Mecânica Aplicada Teses. 3. Modelo multicorpo do veículo;. 4. ABS; . 5. ESP;. 6. 4WS;. 7. Controle integrado;. 8. Cenários críticos de condução.. I. Ingo Weber, Hans. II. Rill, Georg. III. Pontifícia Universidade Católica do Rio de Janeiro. Departamento de Engenharia Mecânica. IV. Título. 
To my family, for their support and encouragement. 


\section{Acknowledgements}

I start my list of acknowledgments expressing my greatest gratitude and love to my family, the most important people of my life, my mother Nelly, my grandmother Gumercinda, my sister Dayana and my uncle Johan. For always supporting me, and for always encourage me to face the difficulties of life.

At the beginning of this thesis program I had some difficulties to find a research topic. However, Prof. Hans Ingo Weber, who is my advisor, encouraged me to continue in a very interesting field of mechanics, the multibody systems and specifically, road vehicle dynamics. Therefore, I would like to thank him for all the support and also for all the knowledge on mechanics that he shared with me over the years of the doctorate program. After the second year of the doctoral program I got a co-advisor, Prof. Georg Rill. He welcomed me to his laboratory at OTH Regensburg in Germany. I am very grateful to him for all the knowledge on vehicle dynamics that he shared with me during my work at OTH Regensburg. Also, I would like to express my gratitude to him for all the recommendations and suggestions about professional and personal aspects. Without their contributions, this thesis would not have been possible. For all of these reasons, I am very grateful to both of them.

Besides my advisor, I would like to thank the members of my thesis committee, for having accepted to participate in the evaluation of this work, and for their insightful comments and encouragement made on the day of the thesis defense. These comments were very relevant, and helped me to improve the final version of the thesis manuscript.

I am also grateful for the contributions on my learning and training during my doctoral thesis, to professors Mauro Speranza, Ivan Menezes and Thomas Schaeffer.

During the years of the doctoral program, I spent good times in company of good people and better friends from Mechanical Engineering Department at PUC-Rio. To them I express my gratefulness for the nice moments lived together through the work at PUC-Rio. Thank you very much to: Pedro, Cristian, Smith, Martin, Pavel, Adriano, Marcelo, Juan Jose, Bárbara, Americo, Damien, Gustavo and Guilherme. Special thanks to Bruno Cayres and Arturo Cubas who helped me in key parts of the research process as well as the useful discussions and brainstorming sessions, specially during the difficult conceptual development stage.

Besides my time at PUC-Rio, I spent nine months at OTH Regensburg, where I made good friends also. A very special thanks to Bernd Gamisch, Steffan Maier, Thomas Dunkes, Andreas, Mathias, Johannes and Simon. 
Special thanks also to Rafael Basilio for helping me during the test with the scaled vehicle model performed at OTH Regensburg.

Finally, for their financial support during the years of the doctoral program, I would like to thank CAPES and CNPq for the scholarship in Brazil, and the Mehrköpersimulation Labor of the OTH Regensburg for the opportunity to use their installation during my working period there. 


\section{Abstract}

Arrieta Castro, Abel; Ingo Weber, Hans (Advisor); Rill, Georg (CoAdvisor). Development of a robust and fault tolerant integrated control system to improve the stability of road vehicles in critical driving scenarios. Rio de Janeiro, 2017. 106p. Tese de Doutorado - Departamento de Engenharia Mecânica, Pontifícia Universidade Católica do Rio de Janeiro.

Nowadays new technologies are pushing the road vehicle limits further. Promising applications, e.g. self-driving cars, requires control systems that are able to ensure the vehicle's stability during autonomous driving or under dangerous scenarios. In most of modern cars, the control systems actuates independently, i.e. there is no coordination or data sharing between them. This approach can produce conflicts between these standalone controllers, thereby no improvements on the vehicle's stability are achieved or even a worse scenario can be produced. In order to overcome these problems, an integrated approach is designed in this work. This integration, defined as Integrated control system (IC), use a rule to coordinate the Electronic stability program (ESP) and the Four-wheel steering system (4WS). The ESP performs a selective braking depending of the current state of the vehicle. This condition is estimated by the difference between the desired yaw rate, obtained using a linear vehicle model, and the actual yaw rate. In addition, the braking pressures at each wheel are computed by the Anti-lock braking system (ABS). In this work, an on-off switching logic and a firstorder hydraulic model are employed to model the ABS system. To model the $4 \mathrm{WS}$, a simple feed-forward control strategy that consider the front steering as input is used. Finally, in order to test the advantages of the IC system against the non-integrated one, simulations considering a nonlinear vehicle model under critical driving scenarios were performed. The vehicle model was derived employing the multibody approach and the Jourdain's principle, and then it is validated using a set of experimental data obtained by sensors mounted on a scaled car.

\section{Keywords}

Multibody vehicle model; $\quad$ ABS; ESP; $4 \mathrm{WS} ; \quad$ Integrated control system; Critical driving scenarios. 


\section{Resumo}

Arrieta Castro, Abel; Ingo Weber, Hans; Rill, Georg. Desenvolvimento de um sistema de controle integrado robusto e tolerante a falhas para melhorar a estabilidade de veículos em cenários críticos de condução. Rio de Janeiro, 2017. 106p. Tese de Doutorado - Departamento de Engenharia Mecânica, Pontifícia Universidade Católica do Rio de Janeiro.

Atualmente, as novas tecnologias estão estendendo os limites físicos dos veículos automotivos em busca de mais segurança e comforto. Novas aplicações, como por exemplo veículos autônomos, exigem sistemas de controle capazes de garantir a estabilidade do veículo durante a condução autônoma ou em cenários perigosos. Na maioria dos carros modernos, os sistemas de controle atuam de forma independente, ou seja, não há coordenação ou compartilhamento de dados entre eles, pois poderiam produzir conflitos entre esses controladores. Desse modo, nenhuma melhoria na estabilidade do veículo é alcançada ou inclusive, piores cenários podem ser produzidos. Para superar esses problemas, uma abordagem integrada é projetada neste trabalho. Esta integração, definida como sistema de controle integrado (IC), usa uma regra para coordenar o programa eletrônico de estabilidade (ESP em inglês) e o sistema de direção de quatro rodas (4WS em inglês). O ESP realiza uma frenagem seletiva dependendo do estado atual do veículo. Esta condição é estimada pela diferença entre a taxa de guinada desejada, obtida usando um modelo linear do veículo, e a taxa de guinada real. Adicionalmente, as pressões de frenagem em cada roda são calculadas pelo sistema de travagem antibloqueio (ABS em inglês). Neste trabalho, uma lógica de comutação on-off e um modelo hidráulico de primeira ordem são empregadas para modelar o sistema ABS. Para projetar o 4WS, usou-se uma estratégia por alimentação direta que considera o ângulo de esterçamento das roas frontais. Finalmente, para testar as vantagens do sistema IC proposto nesta tese contra o enfoque não integrado, realizaram-se simulações considerando um modelo não-linear do veículo em cenários críticos de condução. O modelo do veículo foi derivado empregando a abordagem multicorpos e o princípio de Jourdain, e depois é validado usando um conjunto de dados experimentais obtidos por sensores montados em um carro a escala.

\section{Palavras-chave}

Modelo multicorpo do veículo; ABS; ESP; 4WS; Controle integrado; Cenários críticos de condução. 


\section{Contents}

1 Introduction $\quad 21$

$\begin{array}{lll}1.1 & \text { Motivation } & 21\end{array}$

1.2 Literature review and background 24

1.2.1 Overview of multibody systems 24

1.2.2 The vehicle stability problem 26

$\begin{array}{ll}\text { 1.2.3 Stability control systems } & 29\end{array}$

1.3 Thesis contributions 32

1.3.1 A versatile vehicle simulation package 33

1.3.2 Standalone vehicle control systems 33

$\begin{array}{lll}\text { 1.3.3 Integrated control system } & 33\end{array}$

1.4 Thesis outline $\quad 34$

2 Road vehicle modeling $\quad 36$

2.1 Simple handling model 36

$\begin{array}{lll}2.1 .1 & \text { Kinematics } & 38\end{array}$

$\begin{array}{ll}\text { 2.1.2 Equations of motion } & 38\end{array}$

2.2 Multibody vehicle model 41

2.2.1 Modeling considerations 42

2.2.2 Suspension system 43

$\begin{array}{ll}2.2 .3 & \text { Tire modeling }\end{array}$

2.2.4 Kinematics $\quad 53$

$\begin{array}{ll}\text { 2.2.5 Equations of motion } & 57\end{array}$

3 PyCar: A versatile vehicle simulation package $\quad 60$

3.1 Computational vehicle model 60

$\begin{array}{lll}3.1 .1 & \text { Numerical integration } & 61\end{array}$

3.1.2 Virtual test driver 61 
$\begin{array}{lll}3.2 & \text { Animation environment } & 62\end{array}$

3.3 Model validation using PyCar 63

$4 \quad$ Vehicle standalone control systems $\quad 67$

$\begin{array}{lll}4.1 & \text { Antilock braking system - ABS } & 67\end{array}$

$\begin{array}{lll}\text { 4.1.1 Requirements } & 69\end{array}$

$\begin{array}{ll}4.1 .2 \text { Control design } & 70\end{array}$

$\begin{array}{lll}\text { 4.1.3 Performance tests } & 73\end{array}$

4.2 Electronic stability program - ESP $\quad 75$

$\begin{array}{lll}\text { 4.2.1 } & \text { Requirements } & 78\end{array}$

$\begin{array}{lll}\text { 4.2.2 Control design } & 79\end{array}$

$\begin{array}{lll}\text { 4.2.3 Performance test } & 79\end{array}$

4.3 Four-wheel steering system - 4WS 81

4.3.1 Control design $\quad 81$

$\begin{array}{lll}\text { 4.3.2 Performance test } & 81\end{array}$

$5 \quad$ Integrated control system $\quad 85$

5.1 Control design $\quad 85$

5.2 Performance test $\quad 86$

6 Conclusions $\quad 89$

$\begin{array}{lll}6.1 & \text { Further work } & 90\end{array}$

$\begin{array}{lr}\text { Bibliography } & 92\end{array}$

$\begin{array}{lll}\text { A Double wishbone suspension kinematic constraints } & 99\end{array}$

A.1 Constraint equations: wheel up/down motion $\quad 99$

$\begin{array}{ll}\text { A.2 Constraint equations: rack displacement } & 101\end{array}$

$\begin{array}{ll}\text { B Steering tendencies } & 104\end{array}$

$\begin{array}{lll}\text { B.1 Scaled car } & 104\end{array}$

$\begin{array}{lll}\text { B.2 Fullsize car } & 105\end{array}$

$\begin{array}{lll}\text { B.3 } & \text { Midsize car } & 106\end{array}$ 


\section{List of figures}

Figure 1. Road fatalities rates around the globe per 100000 population [2]. 21 Figure 2 . EU road fatalities evolution since 1991 and target for 2020 [3]. 22 Figure 3 . Active safety devices percentage of the top 50 best selling cars [7]. 23 Figure 4 . Common elements of a quarter-car model. 25

Figure 5 . Tire forces and torques in the contact area. 27

Figure 6 . Coordinate system and states of the planar vehicle model. $\quad 27$

Figure 7 . Lateral force and tire deformation at the contact patch. 28

Figure 8 . Typical curve of tire longitudinal force in different road sur$\begin{array}{ll}\text { faces and zones of maximum tire force. } & 29\end{array}$

Figure 9 . ESP braking concept [33]. 31

Figure 10 . Simple handling model (SHM) during a steady-state corner$\begin{array}{ll}\text { ing at low speeds. } & 36\end{array}$

Figure 11. SHM during steady-state cornering at high speeds. 37

Figure 12. Multibody road vehicle model, tire and road system [33]. 42

Figure 13. Degrees of freedom (DOF) of the multibody road vehicle model. Graphic representation modified from [33].

Figure 14 . Multipurpose suspension systems: double wishbone, McPherson and multi-link.

Figure 15. Double wishbone suspension layout (front left) and components. The graphic depiction was modified from [33].

Figure 16 . Basic representation of a pure wheel up/down motion for a double wishbone suspension system.

Figure 17 . Basic representation of a pure lateral rack motion for a double wishbone suspension system.

Figure 18. TMeasy contact point and local plane geometry [53]. 
Figure 19. Relationship between forces and slips of a passenger tire computed by TMeasy [33].

Figure 20 . Combined forces at different slips.

Figure 21 . Reference frames employed to describe the kinematics of the multibody vehicle model proposed in this thesis.

Figure 22 . Double lane-change maneuver performed by the PD driver model using the simple handling model at $50 \mathrm{~km} / \mathrm{h}$.

Figure 23. PyCar animation screen-shot.

Figure 24. Three-dimensional CAD model and real scaled car.

64

Figure 25. Top: input steering angle for a double lane change maneuver performed in a surface with a static coefficient of friction of 0.7 approximately. Bottom: controlled longitudinal velocity (black: measurement, gray: PyCar).

Figure 26. Top: lateral acceleration versus time. Bottom: yaw rate versus time in a double lane change maneuver (black: measurement, gray: PyCar).

Figure 27. A simple closed-loop scheme of a commercial ABS system. Figure 28 . Schematic of a Hydraulic modulator with $2 / 2$ solenoid valves of a Bosch GmbH ABS system [19].

Figure 29 . Hydraulic model.

Figure 30 . Wheel dynamics. 70

Figure 31 . ABS control loop structure.

Figure 32 . Single wheel states during braking: with hydraulic dynamics (black line) and without hydraulic dynamics (gray line).

Figure 33 . Braking in a straight line test: solid line (-): ABS-ON, dashed line (- -) ABS-OFF. Top plot: circumferential speeds of front left wheel. Bottom plot: longitudinal slip of the same wheel. Multi-frame shots: trajectory of both vehicles. 
Figure 34 . Braking in a straight line test: solid line (-): ABS-ON, dashed line (- -) ABS-OFF. Top: input $u$ and output pressure $P_{b}$ of the hydraulic system. Bottom: brake torque and normalized longitudinal acceleration. 76 Figure 35 . Braking in a curve test: solid line (-): ABS-ON, dashed line (- -) ABS-OFF. Top plot: circumferential speeds of front left wheel.

Bottom plot: longitudinal slip of the same wheel. Multi-frame shots: trajectory of both vehicles.

Figure 36 . Lateral dynamic response of a road vehicle during an avoiding maneuver at high speeds [45].

Figure 37 . Common components of a commercial Bosch ESP ${ }^{\circledR}[66]$.

Figure 38 . ESP braking concept.

Figure 39. Trajectory and main states of a full-size vehicle during an avoiding maneuver. Top: yaw rate. Bottom: lateral acceleration. ESPON (black line), ESP-OFF (gray line).

Figure 40 . ESP braking activations during avoiding maneuver. 1: front left. 2: front right. 3: rear left. 4: rear right.

Figure 41. Proposed feed-forward control law.

Figure 42 . Trajectory and main states of a full-size vehicle during an avoiding maneuver. Top: yaw rate. Bottom: lateral acceleration. 4WSON (black line), 4WS-OFF (gray line).

Figure 43 . 4WS rear steering activations during the avoiding maneuver.

1: front left. 2: front right. 3: rear left. 4: rear right.

Figure 44 . Trajectory and main states of a full-size vehicle during an avoiding maneuver. Top: yaw rate. Bottom: lateral acceleration. ICON (black line), IC-OFF (gray line).

Figure 45. 4WS rear steering activations during the avoiding maneuver.

1: front left. 2: front right. 3: rear left. 4: rear right. IC-ON (black line), IC-OFF (gray line). 
Figure 46. ESP braking activations during the avoiding maneuver. 1: front left. 2: front right. 3: rear left. 4: rear right. IC-ON (black line), IC-OFF (gray line).

Figure 47. Lower and upper control arms of a double wishbone suspension system.

Figure 48 . Steering tendency of the scaled car.

Figure 49. Steering tendency of a fullsize car.

105

Figure 50 . Steering tendency of a midsize car. 


\section{List of tables}

Table 1. TMeasy tire model parameters for a tire of type Radial 205/50R15 51

Table 2. Reference frames of the proposed multibody vehicle model. $\quad 53$

Table 3. Velocities and angular velocities of all bodies relative to the vehicle-fixed axis system $V$. 56

Table 4. Partial velocities. 59

Table 5. Partial angular velocities. $\quad 59$

Table 6. Simple handling model and Proportional-Derivative driver model parameters. 64

Table 7. Scaled vehicle main inertia and geometric data. 65

Table 8. Full-size vehicle: overall characteristic parameters. $\quad 67$

Table 9. ABS model parameters. 72

$\begin{array}{ll}\text { Table 10. Wheel and hydraulic parameters. } & 72\end{array}$

Table 11. Scaled car: characteristic parameters for the corresponding SHM105

Table 12. Fullsize car: characteristic parameters for the corresponding

$\begin{array}{ll}\text { SHM } & 106\end{array}$

Table 13. Midsize car: characteristic parameters for the corresponding 


\section{List of abbreviations}

ABS

Anti-lock braking system

ESP Electronic stability program

4WS Four-wheel steering system

ASR Anti-slip regulation

AFS Active front steering system

IC Integrated control system

ECU Electronic control unit

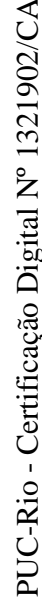

DOF

Degrees of freedom

COG

Center of gravity

MBS

Multibody systems

SHM

Simple handling model

TMeasy

Tire model easy to use

WHO

World Health Organization

EC

European Commission

EU

European Union

ISO

International Organization for Standardization 


\section{List of symbols}

Mathematical objects within this thesis are denoted as follows:

$$
\begin{gathered}
\text { m - scalar } \\
\boldsymbol{m} \text { - vector }, \\
\boldsymbol{M} \text { - matrix }
\end{gathered}
$$

When present, symbols in sub- and superscripts of a variable $r$ are employed in the form $r_{1,2}^{3}$. The numbers denote the position of the following optional assignments:

1 - a position, e.g. $W$ for wheel center

2 - the coordinate system in which the variable is measured, e.g. $V$ for vehicle-fixed axis system

3 - an exponent or an additional assignment, e.g. $r^{\text {min }}$ for the minimum value of $r$

\section{Coordinate systems}

$\left\{O_{V}, x_{V}, y_{V}, z_{V}\right\} \quad$ origin and Cartesian coordinate axes of vehicle-fixed axis system

$\left\{O_{C}, x_{C}, y_{C}, z_{C}\right\} \quad$ origin and Cartesian coordinate axes of chassis-fixed axis system

$\left\{O_{W i}, x_{W i}, y_{W i}, z_{W i}\right\} \quad$ origin and Cartesian coordinate axes of $i$-th wheel-fixed axis system

$\left\{O_{K i}, x_{K i}, y_{K i}, z_{K i}\right\} \quad$ origin and Cartesian coordinate axes of $i$-th knucklefixed axis system

$\{O, x, y, z\} \quad$ origin and Cartesian coordinate axes of global coordinate system (inertial frame) 


\section{Variables, parameters and constants ${ }^{1}$}

$m \quad$ vehicle mass

$\Theta \quad$ vehicle moment of inertia around $z_{V}$ axis

$\delta_{i} \quad$ steering angle at the inner wheel

$\delta_{o} \quad$ steering angle at the outer wheel

$\delta \quad$ mean steering angle

$l_{f}$ distance from vehicle's COG to front axle

$l_{r} \quad$ distance from vehicle's COG to rear axle

$l \quad$ vehicle's wheel base

$w \quad$ vehicle's track width

$\beta \quad$ vehicle's sideslip angle

$\dot{\psi} \quad$ vehicle's yaw rate

$\alpha \quad$ vehicle roll angle

$\gamma \quad$ vehicle yaw angle

$\boldsymbol{v} \quad$ vehicle's velocity at COG

$z_{i} \quad$ vertical displacement of $i$-th wheel relative to the chassis

$\rho \quad$ upper control arm rotation angle

$e_{\rho} \quad$ upper control arm axis of rotation

$\phi \quad$ lower control arm rotation angle

$e_{\phi} \quad$ lower control arm axis of rotation

$\delta \quad$ steering angle around the kingpin axis

$e_{\delta} \quad$ kingpin rotation axis

$u_{F}$ front rack displacement

$u_{R}$ rear rack displacement

\footnotetext{
${ }^{1}$ SI units are used throughout this manuscript. Unless specifically noted otherwise, the unit radians was used for all angles.
} 


$$
\begin{array}{ll}
R & \text { radius of curvature } \\
\mathcal{I} & \text { instantaneous center of rotation } \\
i & \text { wheel index, } i=\{f l, f r, r l, r r\} \\
j & \text { axle index, } i=\{f, r\} \\
\boldsymbol{F} & \text { vector of tire forces at contact point } \\
s_{x} & \text { longitudinal tire slip } \\
s_{y} & \text { lateral tire slip } \\
r_{D} & \text { dynamic tire radius } \\
r_{S} & \text { static tire radius } \\
\Omega_{i} & \text { absolute angular velocity of } i \text {-th wheel } \\
\omega_{i} & \text { rotational speed of } i \text {-th wheel } \\
e_{y R} & \text { wheel rotation axis } \\
K_{f} & \text { cornering stiffness at front axle } \\
K_{r} & \text { cornering stiffness at rear axle }
\end{array}
$$


Wisdom must be intuitive reason combined with scientific knowledge.

Aristotle, Nicomacheian Ethics, VI.7. 